SCIENTIFIC RESEARCH 



\title{
A BRIEF ACCOUNT OF WHAT THE FEMINIST METHODOLOGY OF INTERSECTIONAL ANALYSIS REVEALS ABOUT TERRORISM STUDIES
}

\author{
Marcin KUPIECKI ${ }^{1}$, M.A.
}

"The fight against terrorism is also a fight for the rights and dignity of women", claimed Laura Bush in her radio address in the first few months following the 11 September 2001 attack on the World Trade Center in New York City. Her understanding of the issue of female involvement in terrorism, whether in active warfare or otherwise, although noble, showcased a limited and primitive outlook on the situation. This essay will show that the incorporation of intersectionality into feminist thought can enrich and deepen our understanding of both feminism and terrorism studies. Firstly, it will define intersectionality and show the ways it fits into feminist political theory by looking at its origins and advantages. Later, it will move into a discussion of the different ways in which women and terrorism converge and how intersectionality can help us broaden our understanding of those fields of study.

Many hail intersectionality to be one of the most welcome, important and revolutionary additions to feminism (Davis, 2008: 67) - an area of study that, among many other things, seeks to uncover the systems of oppression that push women to be mistreated, misunderstood and marginalised on the basis of

1 Marcin Kupiecki completes his M.A. studies in International Relations at the University of St. Andrews (Scotland, UK). 
their gender. In the 1960s and 70s, having gained momentum after their recent emergence, feminist and race-related movements were regarded as "the nuisance of their times" by conservative academics (Said, 1985: 98). In an attempt to be seen as serious, relevant and valid, they often only explored the basic premise of their existence, resulting, for instance, in feminism's tight focus on describing patriarchy and its affairs. At the time, it gave little to no attention to the plight of women of colour or non-heteronormative females, let alone to patriarchy's negative impacts on men. Conversely, academics focusing on race dedicated almost no space to women in their writings. Emerging several decades later, however, is intersectionality, an academic approach that pierces through people's identities like a thread, weaving them together rather than rounding them up into separate and never-overlapping entities. This timing is understandable, as thinking outside of our categorised reality first requires a deep knowledge of each strand of the complex identities that the people who dwell in it have (Bedolla, 2014: 448).

Kimberlé Crenshaw was the first feminist writer to explicitly focus on intersectionality and noted the need to narrate women's experiences, not only through their functioning in a patriarchal society, but also through facets of their identity that go beyond gender - primarily race, but also social class, sexual orientation or level of education (Crenshaw, 1991: 1242). She voiced the need to identify how the multiplicity of these other categories, as well as their intertwinement, construct power structures and shape women's social and political lives (Davis, 2008: 71). In simple terms, if all women are victims of structural inequality and their credentials, rights and voices are undermined based solely on their gender, how does the inequality they experience differ when they are white or black, hetero- or homo-sexual, rich or poor? Intersectionality attempts to answer this question by bringing together identities that have usually been studied separately.It upsets existing binaries (female-male, white-black, etc.) by merging them together to the point of resembling a Venn diagram more than separate entities.

This approach touches upon feminism's essential normative problem - the variations among women, who are not a uniform mass and in their shared similarities, but are distinguished by their differences, especially in the light of discourses that were designed to respond to only one aspect of their identities, never multiple ones (Crenshaw, 1991: 1243). This becomes increasingly significant as it 
bridges feminist critical theory and postmodern feminist methodology "in ways that could not have been envisioned before" (Davis, 2008: 73).Postmodernism was preoccupied with dismissing categorical thinking, instead pushing for universalism across disciplines, as also in feminism.This essentially meant the deconstruction of categories of difference and their removal from feminist thinking at the bud.The concern with this, expressed by critical theorists of gender, race and class, was that insufficient attention would be attributed to the experiences of certain women and mainly those who experience oppression by virtue of skin colour or financial capabilities(Davis, 2008: 74). Such a relativisation of categories of identity could lead to further marginalisation of women who possess them (Bedolla, 2014: 452). Thus, intersectionality proved to be a useful tool by doing two things at once. On the one hand, it dismantles the limiting boundaries that separate feminism from race or class studies by merging them together. On the other, precisely by doing that, it still provides an identity-based outlook on the lives of women.

Indeed, this is the main advantage of intersectionality - encouraging complexity and variation without denying unity. It links the two approaches mentioned above by "making the social and material consequences of the categories of gender/race/class visible" but "by employing methodologies compatible with the poststructuralist project of deconstructing categories" (Crenshaw, 1991: 1243). Although it is praised for giving a voice to groups otherwise marginalised, some call for more framework and methodology to be introduced, allowing clearer standards of analysis (Said, 1985: 91). However, according to others, whatserves as its biggest asset is precisely its seeming ambiguity (Davis, 2008: 69).Thus, intersectionality constitutes a holistic and fair analytical tool within feminism. The rest of this essay will aim to explain what the feminist methodology of intersectional analysis can reveal about terrorism studies, focusing on the effects of the post-9/11 War on Terror for illustration. To do so, it will analyse one of the November 2001 United States presidential radio addresses delivered, as an exception, byformer first lady, Laura Bush.

In her broadcast, Laura Bush spoke of the "brutality against women and children by the Al-Qaeda terrorist network and the regime it supports in Afghanistan, the Taliban" (Bush, 2001). She believed that the violence "is a matter of deliberate human cruelty carried out by those who seek to intimidate and control" and that the "civilised world" condemns all terrorist actions.In her view, they not only 
damage Afghan society, but also want to impose similar control and violence on the aforementioned "civilised world". She proceeds to note that due to American intervention in the region, the plight of women in the area has been largely alleviated but terrorists are "plotting" to once again disrupt the peace. They must be fought to protect the "dignity of women", understood as both the ones in Afghanistan and those in the US and the rest of the "civilised world" (Bush, 2001). Her speech presents the oppression of women as a central goal for the terrorists and is characterised by its far-reaching superficiality. Furthermore, it sets up several dangerous dichotomies, following an "us versus them" mode of thinking (civilisation vs. Afghanistan, democracy vs. terrorism, "our women" vs. "their women" etc.). This brings to mind Edward Said's work on Orientalism and the concept of the "Other", out ofwhich the Western world has been shaping narratives about the Orient in ways that deny agency and render voiceless all nonWesterns, "Other" centres of knowledge (Said, 1985: 105). Moreover, he explains that Oriental culture has been feminised, by describing it through illustrations of harems, belly dancing and veils andfertile lands as mysterious and inaccessible, one that has to be first explored, then silenced to give room for the discussion of our own perception of how it should be conceived of (103). His portrayal of Western ideas about the Orient is in line with feminist writings on patriarchy's abuse of women. Without ever using the term, Said supports feminism's integration of intersectionality, when calling for more cross-discipline analysis and adoption of identity narratives in an effort focused on "dismantling systems of domination" that are collectively built and sustained and, therefore, must be collectively brought down (106). Feminist and ethnic studies are brought together for communal, nonfactional benefit, just like Crenshaw's intersectionality envisioned it (91).

This interesting link between Orientalism and feminism becomes valuable in the context of Bush's speech, as we realise that her views on the lives of women both at home and abroad, broadcast to the entire nation, are not only simplistic and hurtful, but also holding back the understanding of femininity. Her concern with terrorism in the context of women's lives is a misrepresentation of its effects on women's political and social lives around the world. Feminist intersectionality can help set the record straight.Firstly,it is important to pronounce the role of women within terrorist organisations. They are typically portrayed as passive caretakers, whose main contributions within such groups revolve around bringing up future terrorists and supplying petty services like cooking or cleaning, much in the 
vain of the Western "camp followers" (Steans, 2010: 56).Women, however, also take an active part in terrorism. In countries like Afghanistan, they are seen as having a responsibility towards their society, namely protecting it against moral degradation and providing support to male warriors, both stemming from a patriarchal and traditional understanding of female virtues in conservative Muslim circles, where men are decision makers who guide women through life and, in a sense, define them as human beings, for instance through marriage (Beyler, 2004). In our understanding of Islam and terrorism, this has often led to the portrayal of Muslim women as helpless and without agency, even if they engage in terrorism more proactively. While men's actions were always understood to be ideological, fuelled by political and religious beliefs, women were portrayed as acting on a different set of motivations (Sjoberg and Gentry, 2011: 77). They were thought to become jihad warriors in order to avenge the death of their sons and husbands or their own suffering, for example rape by a Western soldier. Focus on ideological responses, where women decided to fight for their beliefs and an expression of their own religious zeal was overshadowed by looking primarily at emotional responses (Bloom, 2005). However, women are noted to have been slowly stepping out of their role as mother, educator and religious preacher and into that of an active jihadi warrior in recent years (Beyler, 2004). Intersectionality can thus uncover the modes of operation for these processes and inform us about them to encouragebetter methods of dealing with them, both theoretically and in practice.

The prevailing image of a terrorist is one of a radical Muslim male when, in fact, terrorists come from different ideological backgrounds, are of all races and not exclusively male. When either white or non-Muslim females engage in terrorism in troubled areas or veiled Muslims lead peaceful lives in the West, assumptions and expectations are broken (Sjoberg and Gentry, 2011: 180). Women have been gaining more attention in political literature in recent years, mirroring their expanding engagement in active terrorism. Since 1985, approximately $34 \%$ of all attacks around the world have been carried out by females and the figures keep growing (Bloom, 2005). In the face of such rising numbers, specialist literature had to comment on this process, producing figures such as the ones above. However, it had to go deeper to truly understand the concrete examples of females' involvement in terrorism. Intersectionality allows us to truly understand their motives, which are plentiful because of the diversity of women who get 
involved.Examples of this range from the life and activities ofGerman secular Red Army Faction leader, Ulrike Meinhof, to the experiences of veiled women living in the US or UK (McRobie, 2013). An intersectional approach to feminism understands and studies these complex identities and informs us about them, leading to a more holistic perspective on women's involvement in terrorism. One that might lead to bringing an actual positive change to females whose lives have become intertwined with terrorism, unlike Bush's speech.

Her address claimed the conditions of living for women in the West are endangered by terrorism. Fighting it would thus ensure security in "civilised countries" and an improved situation for women in Afghanistan. The reality, as we have seen evolving in the past decade and beyond, could not be further from that. US bombings in the Middle East killed thousands and have destroyed the homes of many families. In many cases, in more traditional settings, this resulted in men feeling the need to mobilise and, depending on their beliefs, join terrorist cells, only furthering the problem or dislocating to areas where work was more readily available to provide for their loved ones. Meanwhile, women were left behind to take care of their families with little to no resources, feeling helpless (Steans, 2010: 54). They were often abused by rebels, soldiers or other refugees. Forced into hunger, poverty or prostitution, their standards of living plummeted (McRobie, 2013), going against what Bush claimed in her speech.Similarly, the lives of women in "civilised countries" were often put at risk by involvement in and the treatment of terrorism-related issues by the US and its allies. In the UK alone, hundreds of families were affected by the War or Terror. Many British citizens of Middle Eastern descent suspected of terrorist activities were imprisoned, tortured and oppressed in order to be found innocent in the end. Unnecessary measures rooted in prejudice pushed women and their families into poverty, shunned them from society, deprived them of their loved ones and confronted them with deportation, which could result in imprisonment or death in a place that was no longer or has never been their home (Brittain, 2013).

Therefore, intersectionality can help us understand the systems of oppression that led Bush to believe that terrorism is an immediate problem solely for "noncivilised" countries where US intervention couldalleviate the problem while firmly protecting the West. Because of complex identities, such a divide is unrealistic 
and harmful, leading people to misunderstand the nature of some forms of terrorism as well as the effect counteraction to terrorism can have on people's lives. Intersectionality breaks boundariesand allows a deeper understanding of issues such as women's roles in terrorism.

\section{Bibliography}

Bedolla, L. G., 2014. How an Intersectional Approach Can Help to Transform the University. Politics \& Gender. 10(3), pp. 447-455.

Beyler, C., 2004. Female Suicide Bombers: an update. International Institute for Counter-Terro rism. Availableat:<http://www.ict.org.il/Articles.aspx?SortID $=0 \&$ from $=01 / 01 / 1948 \&$ to $=01 /$ 01/2050\&WorkerID $=266 \&$ OrgID $=0 \& A t t a c k I D=0 \& R e g i o n I D=0 \& W o r d I D=0>\quad$ Accessed on 19 November 2014].

Bloom, M., 2005. Terror's Stealth Weapon: women. Los Angeles Times Online. [Online] November 29. Available at:< http://articles.latimes.com/2005/nov/29/opinion/oebloom29> [Accessed on 17 November 2014].

Brittain, V., 2013.How the 'war on terror' in England became a war on women and children. [online] Al Jazeera. Available at:<http://www.aljazeera.com/indepth/ opinion/2013/03/20133912211317464.html> [Accessed 20 April 2014]

Bush, L., 2001. Text:Laura Bush on Taliban Oppression of Women. [online] The Washington Post, Available at:<http://www.washingtonpost.com/wpsrv/nation/specials/attacked/ transcripts/laurabushtext_111701.html>. [Accessed 20 April 2014].

Cohn, C. and Enloe, C., 2003. A Conversation with Cynthia Enloe: Feminists Look at Masculinity and the Men Who Wage War. Signs: Journal of Women in Culture and Society, 28(4), pp. 1187-1207.

Crenshaw, K., 1991. Mapping the Margins: Intersectionality, Identity Politics, and Violence Against Women of Color. Stanford Law Review,43(1), pp.1241-1266.

Davis, K., 2008. Intersectionality as Buzzword: a sociology of science perspective on what makes a feminist theory successful. Feminist Theory, 9(1), pp. 67-85.

McRobie, H., 2013. From the war on terror to austerity: a lost decade for women and human rights. [online] Open Democracy. Available at:<http://www.opendemocracy. net/5050/heather-mcrobie/from-war-on-terror-to-austerity-lost-decade-for-womenand-human-rights> [Accessed 11 April 2014].

Said, E., 1985. Orientalism Reconsidered. Cultural Critique, 1(1), pp. 89-107.

Sjoberg, L. and Gentry, C.E., eds., 2007. Mothers, Monsters and Whores: Women's Violence in Global Politics. London: Zed Books. 
Sjoberg, L. and Gentry, C.E., 2011. Women, Gender and Terrorism. Athens, Georgia: University of Georgia Press.

Steans, J., 2010. Gender and International Relations. Cambridge: Polity Press.

Stone, A., 2004. Essentialism and Anti-Essentialism in Feminist Philosophy.Journal of Moral Philosophy, 1(2). 